\title{
KOLABORASI KLEPTOKRASI BIROKRASI DAN KORPORASI
}

\author{
Abdul Wahid \\ Pascasarjana Universitas Universitas Islam Malang \\ Jalan Mayjen Haryono 193 Malang 65144 \\ Telephone: (0341) 551932, 551822, Fax.: (0341) 552249 \\ Email: visibos@yahoo.com
}

\begin{abstract}
Collaboration of kleptocracy practice among bureaucrats and corporation takes place quite several times. They do not consider the negative consequences which might influence a lot of people. They cooperate in coping with development projects whose handling is not undergone as it should be allocated in the budget. These projects are brought into reality but they have very low qualities because of the budget misuse. In addition, there are many development projects which do not generate satisfying results because half of the budget is corrupted by both bureaucrats and corporates. Corruption committed by both bureaucrats and corporates could be found or at least it could be assumed when the handling process of the development projects is finished haphazardly.
\end{abstract}

Key words: bureaucracy, corporation, corruption, kleptocracy, development

\begin{abstract}
ABSTRAK
Kolaborasi praktik kleptokrasi antara birokrat dengan korporasi sudah demikian sering terjadi. Mereka tidak mempertimbangkan akibat buruk perbuatannya yang menimpa masyarakat. Mereka menjalin kerjasama dalam penanganan proyek-proyek pembangunan, yang penanganannya tidak dijalankannya sesuai dengan alokasi anggaran. Proyek-proyek ini memang terwujud, akan tetapi kualitasnya rendah akibat anggaran yang semestinya digunakan secara maksimal, justru disalahgunakannya. Sudah demikian banyak proyek-proyek pembangunan yang tidak memberikan hasil yang memuaskan akibat sebagian anggarannya dikorupsi secara berjamaah antara birokrat dengan pelaku korporasi. Korupsi dari kolaborasi pelaku korporasi dengan birokrasi ini dapat ditemukan, minimal dibaca sebagai dugaan ketika penanganan proyek pembangunan bersifat asal jadi.
\end{abstract}

Kata kunci: birokrasi, korporasi, korupsi, kleptokrasi, pembangunan

\section{PENDAHULUAN}

"The danger of small mistakes is that those mistakes are not always small (bahayanya kesalahan-kesalahan kecil adalah bahwa kesalahan-kesalahan itu tidak selalu kecil)."

Kata mutiara itu sebenarnya mengingatkan kita untuk tidak gampang mengabaikan masalah kecil, apalagi masalahnya "orang kecil" karena sebenarnya masalahnya "orang kecil” merupakan masalah besar. ${ }^{1}$ Masyarakat kecil ini umumnya menghadapi masalah akibat sikap dan perilaku orang besar yang gampang menyusahkan orang kecil. Orang kecil menjadi semakin menderita ketika hakhaknya secara terus menerus "dirampok" (dikleptokrasi). ${ }^{2}$ Orang besar yang diingatkan

Abdul Wahid, (2010), Negara Tanpa Kelamin, Surabaya: Marshindo, hlm. 54.

Amarullah Sunhaji, (2011), "Pembantaian” Orang Kecil, Catatan atas Pelanggaran Hak Asasi Manusia, Jakarta: Bestari Media, hlm. 22. 
ini, diantaranya adalah para aparat atau pejabat pemerintahan (birokrat) dan para pemilik perusahaan atau badan usaha (korporasi).

Di tangan birokrat, banyak urusan besar yang berelasi dengan kepentingan orang kecil. Ketika terjadi pengabaian kepentingan orang kecil, maka praktik demikian dapat dikategorikan sebagai dehumanisasi oleh birokrat. Akibat mengerikannya, orang kecil menerima kesengsaraan berlapis-lapis. Sementara itu korporasi merupakan deskripsi dari institusi dengan komunitas pemilik modal, karena di tangannya ada banyak uang yang bisa digunakan untuk membangun dan mengembangkan bisnis. Jika peluang-peluang mereka mengembangkan sektor bisnis yang berbasis kerakyatan terhambat oleh birokrat, maka jelas rakyat yang menderita kerugian besar. Rakyat dari kalangan kecil di Indonesia misalnya, paling serng dan banyak menerima penderitaan berlipat akibat korupsi.

Kerugian (penderitaan) itu bisa menjadi lebih besar dan eskalatif serta masif bilamana birokratnya menjadi segmentasi dari mafia birokrasi yang berkolaborasi dengan korporasi atau pelaku usaha yang "nakal" (baca: kriminal), yang menjadikan birokrasi sebagai instrumen untuk mendapatkan, memapankan, dan memperluas kepentingan yang dijalankan secara ilegalitas. ${ }^{3}$ Praktik birokrat demikian ini merupakan "virus" mengerikan yang menyerang masyarakat. ${ }^{4}$ Mafia birokrasi ini menjadi wujud dari jenis deviasi yang dilakukan seseorang atau beberapa orang yang secara general saling mengikatkan diri dalam prinsip simbiosis mutalisme.

Terbukti, birokrasi yang berkembang di Indonesia saat ini, di satu sisi digambarkan sebagai organisasi yang tidak efisien, berbelitbelit, penganut slogan "kalau bisa dipersulit mengapa dipermudah?" Komposisi pegawai yang semakin membengkak, dan korup. Sebuah gambaran yang membuat kita tidak respect dan takut untuk berhubungan dengan birokrasi. Daripada mencari masalah lebih baik berusaha tidak berurusan dengan yang namanya birokrasi. Di sisi lain, birokrasi digambarkan sebagai sebuah organisasi dimana bisa meraih segalanya bagi siapa saja pemenang sebuah pemilihan, mulai dari uang, jabatan, dan kekuasaan. Dua gambaran yang kontradiktif, karena gambaran yang pertama disampaikan oleh masyarakat bawah dan gambaran kedua disampaikan oleh penguasa (elite). ${ }^{5}$

Abdul Wahid, (2012), Supremasi Mafioso, Jakarta: Nirmana Media, hlm. 23.

Azam Mirda, (2014), Kleptokrasi Birokrasi, Malang: Lembaga Kajian Penguatan Masyarakat (LKPM), hlm. 23.

5 Martin Rambe, (2015), Politisasi Birokrasi di Indonesia, di akses pada tanggal 15 Mei 2016, http://edukasi.kompasiana.com/2013/05/08/politisasi-birokrasi-di-indonesia-558239.html. 
Deskripsi "busuk" atau beragam penyakit birokrasi dan korporasi itu membuat banyak pertanyaan pula yang ditujukan pada identitas Indonesia sebagai negara hukum. Di negara yang mengandalkan supremasi yuridis ini, seharusnya tidak perlu lagi ada beragam atau berlapis praktik-praktik yang berkategori berlawanan dengan norma-norma yuridis, apalagi dilakukan oleh birokrat dan elemen korporasi, yang sebenarnya merupakan sosok yang paham tananan.

\section{PEMBAHASAN}

\section{Kleptokrasi Birokrasi dan Korporasi}

Salah satu "pekerjaan rumah" yang krusial di era pemerintahan Joko Widodo dan Yusuf Kalla adalah menyembuhkan instrumen layanan publik, yang bernama birokrasi. Birokrasi di Indonesia ini jauh dari ideal untuk menjadi instrumen yang kapabel dalam menciptakan atmosfir kondusif terhadap dunia usaha. Di beberapa daerah misalnya, iklim usaha menjadi tidak kondusif dan semakin cenderung monopolistik dan dari aspek ekonomi makin mencekik rakyat, adalah akibat pola layanan birokrasinya berpenyakit "kleptokrasi" (korupsi) birokrasi.

Terjadinya monopoli di sektor usaha atau semakin mengguritanya kekuatan ekonomi pada segelintir orang, juga tidak lepas dari peran yang dimainkan oleh korporasi yang menghegemoni beberapa birokrat. Beberapa pemilik korporasi "dimanjakan" oleh kemudahan, sementara para pemilik modal kecil terabaikan dari layanan yang memudahkannya.

Deskripsi itu menunjukkan, bahwa terdapat praktik diskiminasi birokrasi akibat korporasi tertentu sudah mendapatkan tempat liberal untuk bermain, sementara sekelompok pemilik korporasi bermodal kecil dibuat kehilangan kesemptan menjalankan aktifitas ekonominya secara demokratis, egaliter, dan humanistik.

Misalnya pengembang bermodal kecil mengeluh akibat lamanya urusan perijinan dan adanya biaya tidak tertulis di berbagai pos birokrasi. Ketika proses ini memakan waktu lama dan biaya tidak murah, maka selain pelaku bisnis bermodal kecil ini dirugikan, konsumen juga jelas mengalami kerugian, mulai dari soal harga barang hingga kualitas jasa atau produknya.

Bukti terjadinya kleptokrasi birokrasi itu, diantaranya ditunjukkan oleh sejumlah pelaku bisnis yang secara diam-diam merekam permintaan biaya besar dari kalangan birokrat saat pengurusan ijin bisnisnya. Bahkan ada beberapa birokrat yang dijebaknya, yang berujung "tertangkap tangan" (haterdaad), karena para pelaku bisnis ini mengajak aparat penegak hukum dengan cara menyamar.

Sebagai komparasi riset, saat masih menjadi Wakil Ketua KPK, Mohammad Jasin membenarkan, bahwa kualitas pelayanan publik instansi pemerintah terbilang buruk. Hal tersebut tercermin dari menurunnya angka indeks integritas nasional di tahun 
2010. Angka indeks integritas nasional hasil survei ini adalah 5,42 tergolong jauh dari ideal. Untuk menilai ini, didahului survei yang dilakukan terhadap 353 unit layanan publik instansi pemerintah yang tersebar di 23 instansi pusat, enam instansi vertikal dan 22 pemerintah kota. Jumlah responden pengguna layanan yang dilibatkan dalam survei ini sebanyak 12.616 orang yang terdiri dari 2.763 responden di tingkat pusat, 7.730 responden di tingkat instansi vertikal dan 2.123 responden di tingkat pemerintah kota. Angka yang ditetapkan KPK untuk menunjukkan pelayanan publik yang baik dalam survei itu adalah 6,00 dari skala 0-10. Di bawah angka itu berarti pelayanan dimaksud kurang baik. Sedangkan, angka indeks integritas nasional 5,42 berasal dari perhitungan rata-rata indeks integritas di tingkat pusat dengan 6,16, instansi vertical 5,26 dan indeks di tingkat pemerintah kota yang 5,0. ${ }^{6}$

Temuan KPK tersebut setidaknya sudah memberikan gambaran umum, bahwa dunia birokrasi Indonesia masihlah menjadi penyakit tersendiri bagi masyarakat dan korporasi bermodal kecil. Tidak sedikit hakhak korporasi bermodal kecil yang semestinya harus diwujudkan, justru dibuatnya tertundatunda, berlama-lama dan ditelantarkan diantara jaringan birokrasi bobrok. Salah satu hak korporasi bermodal kecil ini adalah hak memperoleh layanan cepat, demokratis, egaliter, transparan, dan humanistik dalam pengurusan perijinan mendirikan, menjalankan, atau mengembangkan aktifitas bisnis.

Hal ini tidak lepas dari problem klasik, dimana produk regulasinya masih menentukan banyak meja yang harus dilalui oleh setiap pelaku usaha yang bermaksud mendirikan korporasi. Para pengusaha atau investor yang bermaksud beinvestasi di daerah sudah lama mengeluhkan maraknya dan menghegemonunya penyakit "permalingan" (kleptokrasi) yang dilakukan para birokrat Indonesia saat melayani dirinya. Tidak sedikit yang terang-terangan meminta biaya besar kepada pengusaha jika ingin kepentingannya cepat diselesaikan. Kondisi ini diperparah oleh ulah korporasi bermodal besar yang mendapatkan "ruang" lebih liberal dalam "mengendalikan" birokrasi, yang tentu saja mengakibatkan atmosfir kompetisi menjadi tidak sehat.

Sebagai komparasi lagi, memang sebelum tahun 2003, mengurus izin usaha di Singapura sangatlah susah dan "bermeja-meja", sama seperti di Indonesia. Tapi sejak pemerintah negeri Singa ini memakai bizfile, semua proses perizinan sangatlah mudah dan cepat dengan biaya yang sangat terjangkau pengusaha. Proses pengurusan perijinan bisa diselesaikan dalam waktu 1 (satu) hari. Birokrat di negara tetangga ini tidak berlaku

6 Idam Khalid, (2013), Modus Operandi Pelayanan Publik yang Melanggar hak-Hak Publik, Jakarta: Nirmana Media, hlm. 22. 
diskriminatif, yang berbeda dengan birokrat di Indonesia. Mental sebagian birokrat di negeri ini memberikan layanan yang mudah dan terkadan ilegal terhadap korporasi bermodal besar.

Birokrat Indonesia itu, yang sebenarnya tergolong manusia terdidik, tentu saja paham, bahwa pelaku usaha kecil mempunyai hak asasi berkreasi, berinovasi, dan memprogresifitaskan aktifitas ekonominya, padahal, hak asasi manusia (HAM) ini sebagaimana disebutkan oleh tenaga ahli PBB Jan Meterson adalah sesuatu yang melekat dalam diri setiap manusia, yang tanpa dengannya manusia tidak bisa hidup sebagai manusia. ${ }^{7}$ Para pelaku usaha ini bermaksud mengembangkan bisnisnya, yang bisnis ini bukan hanya untuk mencari dan memenuhi hak ekonomi pribadinya, tetapi juga hak ekonomi masyarakat dan negara.

Model birokrat seperti itu, jelas layak digolongkan sebagai birokrat yang bisanya memproduksi "bencana" bagi kalangan pelaku usaha kecil, sehingga dalam ranah demokratisasi ekonomi layak diperlakukan sebagai pelaku pelanggaran HAM serius, karena aktifitas atau perilakunya bukan berwatak membebaskan kesulitan masyarakat, tetapi menutup peluang berkarya dan bekerja seseorang atau sejumlah pelaku usaha kecil, menjagal ekspektasi terwujudnya keadilan yang berkesejahteraan masyarakat, atau menghambat akselerasi penggunaan sumber-sumber ekonomi strategis yang seharusnya bisa diakses dan dinikmati oleh masyarakat secara demokratis.

Birokrat bermental seperti itu jelas berlawanan dengan pasal 9 Undang-undang Nomor 39 Tahun 1999 tentang Hak Asasi manusia disebutkan, bahwa Setiap orang berhak untuk hidup, mempertahankan hidup dan meningkatkan taraf kehidupannya (ayat 1). Setiap orang berhak hidup tenteram, aman, damai, bahagia, sejahtera lahir dan batin (ayat 2), dan setiap orang berhak atas lingkungan hidup yang baik dan sehat (ayat 3).

Budayawan dan Sosiolog AM Rahman ${ }^{8}$ pernah menyebut birokrat seperti itu sebagai duri yang mendekonstruksi kepentingan publik. Di tangan birokrat demikian, kepentingan publik jadi terhambat dan terdestruksi, sehingga kepentingan masyarakat secara makro gagal bisa diwujudkan. Kepentingan masyarakat yang gagal diwujudkan ini dapat memosisikan suatu negara menjadi "negara gagal".

Stigma "negara gagal" disebabkan oleh para pelaku ekonomi (korporasi) dan penyelenggara pemerintahan (birokrat) yang terjerat dalam "kolaborasi hitam". Artinya mereka membuat kompetisi dalam mengembangkan sektor bisnis tidak berjalan secara fair, demokratis, jujur, dan transparan.

Baharuddin Lopa, (1996), Al Qur'an dan Hak-Hak Asasi Manusia. Jakarta:Dana Bhakti Prima Yasa, hlm 76.

A.M Rahman, (2012), Birokrasi Kriminal, Surabaya:Visipress, hlm. 23. 
Dalam ranah itulah, korupsi benar-benar terasa akibatnya bagi masyarakat. Korupsi yang didesain oleh pelaku korporasi deviasi yang berkolaborasi dengan penyelenggara kekuasaan(pemerintahan) telah menghasilkan ketidakadilan, ketidaksejahteraan, dan disparitas dimana-mana. Pemilik korporasi bermodal besar dari waktu ke waktu bisa semakin menggurita, sementara kelompok usaha kecil terpuruk dalam kehancuran.

\section{Komparasi Kasus}

Kasus korupsi yang dilakukan oleh korporasi telah mengakibatkan "bencana" di berbagai sektor kehidupan bermasyarakat dan bernegara. Jika korupsi korporasi ini berelasi dengan proyek-proyek bernilai besar, maka "bencana" yang diakibatkannya pun bersifat mengerikan.

Sebagai sampel analisis, dalam berbagai invesitigasi dugaan korupsi pembangunan jembatan di Indonesia, banyak ditengarai adanya "permainan" antara pengambil kebijakan atau penyelenggara kekuasaan dengan kalangan korporasi. Posisi korporasi disini adalah pelaksana proyek, pemenang tender, atau istilah populernya adalah "mitra pemerintah" dalam penyelenggaraan pembangunan, termasuk pembangunan jembatan.

Suatu jenis pembangunan jembatan yang semestinya bisa digunakan untuk menjembatani atau melindungi hak-hak publik minimal 25 tahun, yang kemudian baru berumur 10 tahun jembatan itu ambruk, tentu saja sangat wajar jika menimbulkan pertanyaan mengapa jembatan yang masih berusia muda ini sampai ambruk?

Perencanaan peruntukan jembatan yang semestinya 25 tahun, namun baru berusia 10 tahun sudah hancur ini, setidaknya mengindikasikan kalau ada yang tidak beres dalam pembangunan dan pemeliharaan jembatan, atau tidak salah jika di negeri ini bersemai kedaulatan korupsi pembangunan.

Ketidakberesan itu dalam bahasa lain dikenal dengan penyalahgunaan atau penyimpangan anggaran, baik anggaran dalam peruntukan pembangunan maupun pemeliharaan jembatan. Korupsi anggaran ini menggelinding ke ranah publik sebagai tudingan kuat tanpa bisa dicegah siapapun, pasalnya di berbagai sektor pembangunan di negara ini, nyaris tidak ada instansi yang tidak tersentuh oleh problem (penyakit) korupsi ketika direlasikan dengan korporasi.

Penyakit kronis bangsa (korupsi) itu juga membenarkan tesis Bung Hatta puluhan tahun lalu yang pernah dilontarkan, bahwa korupsi di Indonesia telah membudaya atau telah tumbuh subur dan bermekaran dimana-mana. Terbukti, belum tuntas membahas dan mencurigai satu jenis korupsi di satu instansi, kita sudah dihadapkan dengan realitas munculnya "armada" koruptor di berbagai instansi lainnya, yang melibatkan korporasi.

Pola-pola korupsinya memang ada yang berkembang pesat sesuai dengan kecanggihan 
intelektualitas manusia yang melakukannya, namun juga tak sedikit yang menganut dan memberlakukan pola lama. Adapun yang menggunakan pola lama ini umumnya terkait dengan sumber anggaran dan pihak-pihak yang terlibat.

Beberapa pola korupsi yang diduga dikaitkan dengan robohnya pembangunan jembatan adalah penyunatan, suap-menyuap, atau mark up anggaran, yang sudah sekian lama menjadi segmentasi kultural di lingkaran struktural. Pola ini bisa bertahan karena adanya kerjasama simbiosis mutualisme (saling menguntungkan dan diuntungkan) antara birokrat dengan penerima atau pelaksana proyek.

Bukan cerita usang, kalau setiap pembiayaan proyek pembangunan mestilah ada "biaya khusus" yang harus disiapkan dari pemenang tender atau pihak yang mendapatkan kepercayaan menanganinya. "Biaya khusus" ini bisa saja disiapkan sendiri atau diambilkan ("disunatkan") dari biaya total yang diperoleh dari APBN maupun APBD.

Dari beberapa testimoni pihak-pihak yang pernah mendapatkan atau menangani proyek pembangunan itu, angka $20 \%$ dari total anggaran pembangunan menjadi angka yang secara umum disepakati, baik oleh pelaksana atau penerima proyek maupun dengan pejabat atau dinas yang menjadi mitranya.

Penyunatan atau mark up juga bisa terjadi secara berjenjang dan berlapis, mulai dari pusat hingga daerah. Ketika di pusat sudah dilakukan penyunatan sekian prosen, maka di daerah pun "meneladani" kriminalisasi strukturalnya. Dinas terkait di daerah tidak ingin ketinggalan untuk memanfaatkan dana yang diperuntukkan bagi kepentingan pembangunan fasilitas publik ini.

Dalam logika bisnis yang dijalankan oleh pelaksana pembangunan jembatan, adalah mendapatkan keuntungan berapapun, meski harus dengan menghalalkan segala cara apapun. Pelaksana tidak mau rugi atas proyek pembangunan jembatan yang dibangunnya. Pelaksana ini tentu saja melibatkan korporasi, sehingga tidak salah jika korporasi diduga melakukan korupsi terhadap proyek jembatan.

Paradigma yang ditunjukkan pelaksana pembangunan jembatan, adalah bagaimana proyek pembanguan selesai, dan bukan bagaimana proyek pembangunan jembatan berkualitas. Bukan bagaimana pembangunan jembatan dibangun untuk melindungi atau memediasi kepentingan publik, termasuk melindungi dan menyematkan, serta menyejahterakan masyarakat, tetapi bagaimana jembatan bisa terwujud untuk "menjembatani" kepentingan kapitalistik dan eksklusifistik korporasi dan beberapa elemen kriminalistik para birokrat. 
Nashir ${ }^{9}$ menggugat lewat kalimat "betapa besar dosa sosial yang dilakukan para perampok anggaran jembatan tersebut", yang gugatan ini bisa ditafsirkan secara hermeneutik, bahwa para perampok atau korupsi anggaran pembangunan jembatan, merupakan golongan koruptor yang telah melakukan perampasan hak keberlanjutan hidup manusia lain. Hak hidup pengguna fasilitas publik telah dirampas oleh koruptor yang mengumbar keserakahan dan gigih melanjutkan petualang kleptokrasinya.

Kalau mau melakukan riset secara teliti dan obyektif terhadap pembangunan jembatan di setiap daerah, tentulah apa yang terjadi di Kutai Kartanegara hanya melengkapi kasus rusaknya dan ambruk atau hancurnya sejumlah bangunan jembatan di sejumlah daerah di Indonesia. Ada satu jembatan misalnya yang baru beberapa bulan diresmikan, langsung ambrol akibat terjangan banjir.

Selain berkaca pada sejumlah bangunan jembatan itu, kasus lain yang berkaitan dengan pembangunan fasilitas publik juga layak digunakan sebagai obyek komparasinya. Tidak sedikit misalnya fasilitas infrastruktur seperti gedung SD, yang baru beberapa bulan atau belum lama dibangun, tiba-tiba roboh dan menimpa murid yang sedang mengikuti proses pembelajaran.
Robohnya sejumlah bangunan jembatan atau infrastruktur lain yang berkaitan dengan praktik korupsi anggaran memang konsekuensi hukum kausalitas, artinya ketika kejahatan penyalahgunaan atau penyalahalamatan anggaran masih dijadikan opsi logis oleh elemen birokrasi atau korporasi, maka jatuhnya korban manusia dan harta benda merupakan resiko yang terpaksa harus diterima. Rakyat tidak berdosa akhirnya menjadi tumbal untuk ikut merasakannya.

"larinya" komponen anggaran 20\% atau lebih bukan hanya sebagai bukti pereduksian kualitas proyek bangunan jembatan, tetapi juga suatu kesengajaan untuk menoleransi terjadinya pelanggaran HAM serius. Mereka yang terlibat dalam kasus ini layak dikategorikan melakukan kejahatan ganda, baik yang berhubungan dengan kekayaan negara maupun kemanusiaan.

Mari kita bandingkan pula antara bangunan jembatan Mahakam dengan bangunan lainnya di sejumlah negara yang menghubungkan antara Pulau Lan Tau (dari airport) di Hongkong dengan Pulau Hongkong. Bangunan jembatan di pulau Hongkong ini sangat kuat yang membentang di atas laut. Bangunan jembatan ini juga tidak berbeda dengan jembatan Selat Bosprus di Turki, yang oleh pemerintah dan swasta, kualitas bangunannya menjadi prioritas, dan bukan

\footnotetext{
9 Ahmad Nashir, (2011), Korupsi dan Pembangunan, Surabaya: Kajian Lintas Ilmu, hlm. 3.
} 
perburuan mendapatkan keuntungan ekonomi pribadi dan kolega yang menjadi prioritasnya.

Di negara-negara tersebut, sejak awal suatu proyek pembangunan disampaikan secara transparan kepada publik. Publik sudah dipersilahkan untuk mengawalnya dengan mekanisme yang memudahkan akses baginya. Siapa-siapa pemilik korporasi yang terlibat dalam proyek pembangunan bisa diketahui secara terbuka, yang membuat kemungkinan kesan atau dugaan adanya "permainan" di kalangan birokrat dan korporasi tertentu bisa dicegahnya sejak dini. Model inilah yang masih langka dalam realitasnya di negeri ini, yang akar fundamental kesalahannya dapat ditimpakan pertanggungjawabannya kepada birokrat atau penyelenggara kekuasaan.

\section{Pembaruan yang Menyehatkan Birokrasi}

\section{dan Korporasi}

Birokrat itu sejatinya aparat kekuasaan atau pekerja yang mendapatkan kepercayaan dari negara untuk melayani kepentingan masyarakat sesuai dengan norma yuridis yang mengaturnya. Korporasi bisa diprevensi dari keberanian melakukan korupsi atau melakukan penyuapan adalah ditentukan oleh sikap etis atau perilaku birokratnya.

Adanya kekuasaan yang melekat dalam tugas, kewenangan, atau kewajiban, membuatnya bisa punya kecenderungan dan bahkan akrab dengan berbagai bentuk penyalahgunaan (abuse of power), bilamana dalam dirinya punya "ambisi" besar untuk memperkaya diri. Korporasi yang serakah atau berkeinginan menggurita secara ekonomi merupakan lahan empuk yang membuatnya bisa mewujudkan ambisi memperkaya dirinya sendiri maupun kroni-kroninya.

Para birokrat semestinya memahami bahayanya relasi uang dan kekuasaan. Kalau tidak demikian berbahayanya uang, tentu tidak ada kata mutiara latin berbunyi "abite nummi, ego vos mergam, ne mergar a vobis " yang artunya Pergilah wahai uang, saya akan menenggelamkan kamu, sehingga kamu tidak bisa menenggelamkan saya. ${ }^{10}$ Kekuasaan (birokrasi) memang identik dengan uang, sementara korporasi pun demikian. Di birokrasi, ada uang negara yang dipercayakan pengelolaannya untuk pembangunan. Sedangkan korporasi merupakan pihak yang bergerak di bidang pelaksananya yang realisasinya melibatkan birokrat ("pemberi" proyek).

Ketika birokrat itu memperlakukan birokrasi secara absolut di ranah kekuasaan, maka bisa dipastikan, bahwa penyalahgunaan menjadi pilihan utamanya. Peringatan tentang betapa berbahayanya kekuasaan atau birokrat yang absolut telah lama diungkap oleh Lord Acton dengan mengatakan "power tend to corrupts, absolute power corrupts absolutely". Kemudian tokoh Myanmar,

10 Azam Mirda, (2014), Kleptokrasi Birokrasi, Malang: Lembaga Kajian Penguatan Masyarakat (LPKM), hlm. 5 . 
Aung San Suu Kyi juga sudah lama mengingatkan hal ini dengan mengatakan "It is not power that corrups, but fear. Fear of losing power corrups those who wield it, and fear of the scourge of power corrups those who are subject to it." ${ }^{\prime 1}$ Dengan mengutip kalimat Lord Acton dan Aung San Suu Kyi ini, maka dapat dipahami, bahwa kekuasaan harus dibatasi demi terwujudnya sebuah pemerintahan yang bersih atau terwujudnya proyek pembangunan yang tidak "dihegemoni" oleh koruptor.

Pembatasan kekuasaan tersebut biasa dilakukan dengan dua mekanisme. Pertama, adalah mekanisme yuridis yang mengedepankan regulasi; Kedua, dengan menggunakan mekanisme check and balance antara lembaga-lembaga negara dengan adanya perwujudan pembagian kekuasaan secara fair dari pusat hingga bawah.

Mekanisme pertama dilakukan untuk mendapatkan sebuah kepastian hukum. Maksudnya, setiap korporasi harus diikat dengan regulasi yang membuatnya berkompetisi secara fair, sementara sanksi administrasi bagi birokrat yang melakukan malpraktik birokrasi pun dibuat berkepastian supaya mereka berintegritas dan beretos dalam kinerja. Sedangkan mekanisme kedua dilakukan untuk mendapatkan harmoni yang bermoral kejujuran dan keterbukaan dalam penyelenggaraan negara (birokrasi) secara politis. Artinya dalam penyelenggaraan pembangunan yang melibatkan birokrasi ini, kekuatan politik di DPR atau DPRD misalnya berkeharusan mengawalnya secara obyektif, dan bukan didasarkan keberpihakan pada koncoisme, patronaseisme, dan eksklusifisme aliansi politiknya.

Birokrasi itu merupakan salah satu kekuatan fundamental konstruksi pemerintahan. Artinya faktor dan aktor utama yang turut berperan dalam perwujudan pemerintahan yang bersih (clean government) dan kepemerintahan yang baik (good governance) adalah birokrasi. Dalam posisi dan perannya yang demikian penting, birokrasi sangat menentukan efisiensi dan kualitas pelayanan kepada masyarakat, serta efisiensi dan efektivitas penyelenggaraan pemerintahan dan pembangunan. Berbagai upaya telah dilakukan oleh pemerintah provinsi dan kabupaten/kota, baik dalam bentuk himbauan, kebijakan dan bahkan seperangkat aturan hukum telah disiapkan pemerintah (daerah), apalagi adanya tuntutan yang cukup deras dari masyarakat sebagai penerima layanan untuk dilakukannya reformasi birokrasi dilingkungan

11 Arfan Faiz Muhlizi, (2015), Kriminalisasi Ruang Diskresi dalam Birokrasi, diakses pada tanggal 17 Mei 2016, http://www.rechtsvinding.bphn.go.id/jurnal_online/Mencegah\%20Kriminalisasi\%20Ruang\%20Diskresi\%20 Dalam\%20Birokrasi.pdf 
pemerintahan (daerah). ${ }^{12}$ Reformasi dapat dilakukan dijalur yuridis maupun moral (etik).

Kedua jalur ini akan berpengaruh besar dalam merestorasi relasi birokrasi dengan korporasi.

Di ranah yuridis, mengingat birokrat kita selain terfokus menjadi "mulut undangundang/hukum" dan memanfaatkan regulasi yang mengatur pelaku usaha harus jadi obyek dari "meja ke meja" dalam pengurusan kepentingan bisnisnya, maka jelas dibutuhkan pembaruan norma yuridis untuk menyederhanakannya. Pembaruan regulasi yang memudahkan dan memberikan keadilan bagi setiap pelaku usaha, akan menciptakan atmosfir kondusif guna mengembangkan potensi ekonomi, khususnya di daerah.

Pembaruan atau pembentukan produk legislasi yang diorientasikan mempermudah jalur pengurusan perijinan atau pengelolaan usaha, disamping memprevensi kolaborasi kriminalistik (korupsi), adalah seperti di Singapura, Jepang, Hongkong. Kalau pembentukan produk yuridis, khususnya di daerah terlaksana dengan benar, tepat, dan jujur, maka dua keuntungan jelas bisa diperoleh, yakni terwujudnya atmosfir membangun dan memprogresifitaskan korporasi yang sehat dan terbentuknya mental birokrat yang berkecenderungan menjadi "paedagog" dalam pencegahan berbagai bentuk korupsi.

Menjadi "paedagog" dalam gerakan budaya anti korupsi atau anti penyalahgunaan kekuasaan merupakan gelar hebat bagi birokrat, karena gelar ini diperolehnya dari pembentukan sikap dan perilaku yang bercorak melawan dirinya sendiri, yang memang dalam konstruksi tabiat kekuasaan berkecenderungan melakukan penyimpangan (korupsi). Soal tabiat korupsi kekuasaan atau kekuasaan korup ini dapat terbaca dalam kasus booming pemeriksaan yang dilakukan oleh KPK terhadap pimpinan daerah. Pelaksana Harian Kepala Biro Humas KPK Yuyuk Andriatim bahwa sejak 2004, KPK sudah mengusut 74 kasus yang libatkan kepala daerah. Dari 74 kasus itu, ada 63 kepala daerah yang terjerat. Rinciannya, 52 orang merupakan bupati/wakil bupati dan wali kota/wakil wali kota. Sisanya merupakan gubernur atau wakil gubernur. Sementara ada beberapa kepala daerah yang kena lebih dari 1 kasus, seperti Ratu Atut (mantan Gubernur Banten) dan Gatot Pujo Nugroho (mantan Gubernur Sumatera Utara). ${ }^{13}$

Regulasi yang dibentuk itu (nantinya) juga harus dijaga agar jangan sampai berimbas pada terjadinya kriminalisasi perbuatan administrasi yang dilakukan oleh pejabat

12 Muskamal, (2015), Aktualitas Konsep Birokrasi dalam Menjawab Tantangan Reformasi Birokrasi di Indonesia, diakses 15 Mei 2016, http://makassar.lan.go.id/index.php/survei/publikasi/artikel/463-aktualitaskonsep-birokrasi-dalam-menjawab-tantangan-reformasi-birokrasi-di-indonesia..

13 Oscar Ferri, KPK Tangani 74 Kasus Libatkan Kepala Daerah sejak 2004, diakses pada tanggal 15 Mei 2016 , http://news.liputan6.com/read/2599966/kpk-tangani-74-kasus-libatkan-kepala-daerah-sejak-2004. 
administrasi (birokrat). Kriminalisasi ini bisa menyebabkan makin terkikisnya ruang diskresi sebagai akibat menguatnya ketidakpercayaan terhadap code of live diluar peraturan perundang-undangan tertulis. ${ }^{14}$ Sebaliknya, ketika norma yuridis yang dibentuk sudah berkepastian, birokrat juga jangan "menginpretasikannya" secara liberal dengan atas nama diskresi sebagai pejabat administrasi.

Sehatnya tubuh birokrasi akan mempermudah segala urusan warga negara. Kematangan sistem birokrasi adalah seharusnya mimpi sebuah negara berkembang yang harus dengan penuh kepercayaan dapat tercapai dalam waktu yang tidak lama. Keharusan aparat birokrasi yang capable (ahli) dibidangnya serta memiliki kemampuan menerjemahkan keinginan masyarakat adalah kebutuhan mendesak yang tidak bisa ditawar-tawar lagi. Kapabilitas dan "sehatnya" secara (khususnya) yuridis kalangan birokrat menjadi penentu kualitas pembangunan. Korporasi yang mendapatkan "order" pemerintah, baik di pusat maupun di daerah juga akan kapabel dan sehat dalam menjalankannya, bilamana ada dukungan instrumen yuridis yang berkepastian mengaturnya.
Selain itu birokrasi harus semakin terpacu dibandingkan masyarakat (korporasi) yang dilayaninya. Tidaklah mungkin karakter birokrasi yang cenderung lambat dan apalagi kleptokrat terus dipertahankan saat ini. Adig Suwandi berpendapat, bahwa refomasi birokrasi sudah sangat mendesak untuk meninggalkan watak lama dan warisan sebagai birokrasi tukang pungut untuk didorong menjadi birokrasi yang memberdayakan empowering bureaucratic). ${ }^{15}$ Watak lama para birokrat itu salah satunya bisa disembuhkan oleh pembaruan regulasi atau norma yuridis. Pembaruan perilaku ini sejalan dengan kesejatian orientasi hukum seperti disebut oleh Rosco Pound "law as a tool of social engineering" atau hukum merupakan instrumen atau alat merekayasa (memperbarui) masyarakat. ${ }^{16}$ Kalau di dalam norma yuridis mengatur atau memastikan orientasi pembaruannya, maka subyek sosial dan hukum, termasuk di dalamnya korporasi, akan menaatinya.

Atmasasmita (2014), dalam bukunya yang berjudul "Teori Hukum Integratif" menyebut, bahwa pada dasarnya fungsi hukum sebagai "sarana pembaharuan masyarakat" (law as a tool of social engeneering) relatif masih sesuai dengan pembangunan hukum nasional

Muhlizi, Loc.Cit.

15 Martin Rambe, Op.Cit.

16 Ahmad Ridwan, (2012), Hukum Berbasis Kerakyatan: Catatan Harian Pekerja Hukum, Jakarta: Visimedia, hlm. 35 . 
saat ini, namun perlu juga dilengkapi dengan pemberdayaan birokrasi (beureucratic engineering) yang mengedepankan konsep panutan atau kepemimpinan, sehingga fungsi hukum sebagai sarana pembaharuan dapat menciptakan harmonisasi antara elemen birokrasi dan masyarakat dalam satu wadah yang disebut "beureucratic and social engineering” (BSE). ${ }^{17}$

Pernyataan Atmasasmita itu menunjukkan, bahwa pembaruan norma itu menjadi pijakan setiap pelaku usaha dan birokrat untuk menjalankan aktifitas yang benar, jujur, transparan, dan akuntabel. Dalam pembaruan ini, substansi norma yuridis menjadi ruh yang menentukannya. Substansi ini juga menjadi landasan kepastian mereka dalam menjalankan aktifitasnya.

Secara idealitas, suatu produk norma yuridis yang baik merupakan landasan sakral dan fundamental membentuk masyarakat dan bangsa yang baik pula. Pembangunan tidak akan sampai dimonopoli oleh 'korporasi nakal" dan sindikatif, manakala norma yuridis berkepastian mengikatnya dengan dukungan aparat yang berindependensi dan bermilitansi tinggi dalam mengimplementasikannya.

Lawrence Meir Friedman ${ }^{18}$ menjelaskan masing-masing komponen sistem hukum sebagai berikut:

1) Structure to be sure is one basic and obvious elemen of legal system.

2) The substance is composed of substabtive rules and rules about how institution should behave.

3) Social procces are constantly at work on the law destroying here, renewing there, invigorating here, deadening there, choosing what part of "law" will operate, which part will not; what subtitutes detours and by passes will spring up; what changes will take place openly or societly. For want of a better term, we can call some of these forces the legal culture. It is the element of social attitude and value.

Friedman memang menempatkan struktur hukum sebagai elemen dasar dari sistem hukum, namun tidak mengabaikan surgensinya substansi hukum. Hal ini dapat dipahami mengingat struktur hukum adalah subsistem yang akan menjalankan sebuah sistem hukum. Sementara substansi hukum digambarkan Friedman secara umum terdiri dari dua bagian: peraturan/kaidah substantif dan peraturan tentang bagaimana lembaga penegak hukum harus bekerja. ${ }^{19}$ Pendapat urgensinya substansi normanya. Substansi ini

17 Romli Atmasasmita, diakses pada tanggal 15 Mei 2016, http://www.negarahukum.com/hukum/pembaharuan hukum.html.

18 Lawrence Meir Friedman, (1975), The Legal System, A Social Science Perspective, New York: Russel Sage Foundation.

19 Benny Simon Tabalujan, (2001), Legal Development in Developing Countries (The Role of Legal Culture), Singapore. 
menentukan jiwa konstruksi yuridis. Kalau konstruksi yuridisnya kuat, maka birokrat tidak akan gampang tergelincir mempermainkan tugas, kewajiban, dan kewenangannya, khususnya peran dalam memberikan layanan kepada masyarakat atau kalangan korporasi.

Jika dengan aturan yang diperbarui masih ada dan banyak birokrat yang belum mampu mengadaptasikan peran yang sejalan dengan norma yuridis yang diperbarui, maka hal ini bukan berarti kegagalan dalam memperbarui norma yuridis, tetapi mengindikasikan masih belum sehatnya pelaksana norma yuridis, terutama kalangan aparat penegak hukum dalam mengimplementasikan pola menjerat atau mempertanggungjawabkan birokrat berkategori pelanggar hukum. Dalam ranah ini, aparat penegak hukum juga terjerat memasuki ranah kolaborasi kriminalistik dengan birokrat maupun korporasi korup.

Upaya Pemerintahan Presiden Joko Widodo dan Wakil Presiden Yusuf Kalla untuk membangun dan mempercepat pemerataan kesejahteraan ekonomi dengan mengandalkan kekuatan korporasi, tidak bisa tidak, harus mengandalkan mesin-mesin birokrasi yang bukan hanya bermental kerja kuat dan cerdas, tetapi juga harus berintegritas dalam menjalankan norma yuridis yang mengaturnya.

Ketika norma yuridisnya itu masih mengalami kekurangan disana-sini, tentu opsi fundamental dan sakral untuk menjawabnya adalah dengan memperbarui norma yuridis yang sejalan dengan percepatan pembangunan ekonomi, khususnya di daerah. Jika pembaruan ini nanti dilakukan, maka sanksi tegas, adil, dan egaliter, wajib ditegakkan kepada siapapun diantara birokrat yang terjerumus dalam malapraktik hukum maupun korporasi yang masih berani menjadi "subversi" terhadap norma-norma yuridis yang mengatur penyelenggaraan pembangunan bangsa.

\section{KESIMPULAN}

Kalangan pelaku usaha atau pemilik korporasi merupakan salah satu penentu penbangunan ekonomi. Kinerja pemilik korporasi ditentukan oleh rule of game yang mengaturnya. Pemilik korporasi bisa mempermainkan negara atau kalangan penyelenggara negara dan bahkan rakyat, bilamana mereka diberi kesempatan, toleransi, dan diajak berkolaborasi untuk melakukan berbagai praktik pelanggaran yuridis. Pelanggaran (korupsi) yang dilakukan oleh korporasi ini bisa menjadi semakin liberal atau absolut, manakala diberi kesempatan oleh kalangan birokrat bermental korup. Kedua pihak ini dapat diidealitaskan mampu mewujudkan atmosfir perekonomian Indonesia yang sehar, bilamana berpijak pada norma yuridis yang berkepastian dan berkeadilan.

Pemilik korporasi dapat memberikan kontribusi besar terhadap pembangunan 
ekonomi Indonesia dengan mewujudkan percepatan pemerataan kesejahteraan, bilamana diberi pijakan pengaturan tegas dan mendukung progresifitas usaha-usahanya. Dalam menjalankan aktifitas usaha (ekonomi), mereka dibentuk menjadi kekuatan besar dengan landasan kepastian hukum progresif yang meregulasinya. Landasan inilah yang idealitasnya menjadi salah satu prioritas di era pemerintahan Presiden Joko Widodo dan Wakil Presiden Yusuf Kalla, sementara norma-norma regulasi yang memberikannya kesempatan berkolaborasi kriminalistik (korupsi), harus dideskonstruksi secepatnya dan secermatcermatnya, serta berkelanjutan.

\section{DAFTAR PUSTAKA}

\section{Buku-Buku dan Makalah}

Crittle, S, tt. (2012), The Last Good Father, Jakarta : Voila Books.

Davidsen, S. et al. (2007). Menghentikan Korupsi di Indonesia 2004-2006, Sebuah Survey Tentang Berbagai Kebijakan dan Pendekatan Pada Tingkat Nasional. Jakarta: Usindo.

Dempster, Q. (2006), Whistleblowers Para Pengungkap Fakta, Jakarta: Elsam.

Gie, K,K. (2001), Pemberantasan Korupsi, Untuk Meraih Kemnadirian, Kemakmuran, Kesejahteraan, dan Keadilan. Jakarta: s.n.

Friedman, L,M. (1975). The Legal System, A Social Science Perspective, New York: Russel Sage Foundation.

Harahap, K, (2006), Pemberantasan Korupsi Jalan Tiada Ujung, Bandung: PT. Grafitri.
Khalid, I. (2013), Modus Operandi Pelayanan Publik yang Melanggar hakHak Publik, Jakarta: Nirmana Media.

Klittgard, R. (2001), Membasmi Korupsi, Jakarta: Yayasan Obor Indonesia.

Lopa, B. (1996), Al Qur'an dan Hak-Hak Asasi Manusia. Jakarta: Dana Bhakti Prima Yasa.

Mirda, A. (2014). Kleptokrasi Birokrasi, Malang: Lembaga Kajian Penguatan Masyarakat (LPKM).

Mulyadi, L. (2007). Tindak Pidana Korupsi di Indonesia; Teoritis, Praktik dan Masalahnya, Bandung: P.T. Alumni.

Nashir, A. (2011), Korupsi dan Pembangunan, Surabaya: Kajian Lintas Ilmu.

Rahman, AM, (2012), Birokrasi Kriminal, Surabaya: Visipress.

Ridwan, A, (2012), Hukum Berbasis Kerakyatan: Catatan Harian Pekerja Hukum, Jakarta: Visimedia.

Sunhaji, A, (2011), "Pembantaian" Orang Kecil, Catatan atas Pelanggaran Hak Asasi Manusia, Jakarta: Bestari Media.

Tabalujan, B S, (2001), Legal Development in Developing Countries (The Role of Legal Culture), Singapore.

Wahid, A, (2010), Negara Tanpa Kelamin, Surabaya: Mahirsindo. (2012), Supremasi Mafioso, Jakarta: Nirmana Media.

Wijayanto, R, Z, (2009), Korupsi Mengorupsi Indonesia, Jakarta: Gramedia Pustaka Utama.

\section{Internet}

Atmasasmita, R, (2014), Pembaharuan Hukum. Diakses pada tanggal 15 Mei 2016,http://www.negarahukum.com/hu kum/pembaharuan-hukum.html.

Ferri, O, (2016), KPK Tangani 74 Kasus Libatkan Kepala Daerah Sejak 2004, 
diakses pada tanggal 15 Mei 2016, http://news.liputan6.com/read/2599966/ kpk-tangani-74-kasus-libatkan-kepaladaerah-sejak-2004.

Muskamal, (2015), Aktualitas Konsep Birokrasi dalam Menjawab Tantangan Reformasi Birokrasi di Indonesia, diakses pada tanggal 15 Mei 2016, http://makassar.lan.go.id/index.php/sur vei/publikasi/artikel/463-aktualitaskonsep-birokrasi-dalam-menjawabtantangan-reformasi-birokrasi-diindonesia..

Muhlizi, A, F. (2015), Kriminalisasi Ruang Diskresi dalam Birokrasi, diakses 15 Mei2016,http://www.rechtsvinding.bph n.go.id/jurnal_online/Mencegah\%20Kri minalisasi\%20Ruang\%20Diskresi\%20 Dalam\%2Birokrasi.pdf.

Rambe, M. (2015). Politisasi Birokrasi di Indonesia, diakses pada tanggal $15 \mathrm{Mei}$ 2016,http://edukasi.kompasiana.com/20 13/05/08/politisasi-birokrasi-diindonesia-558239.html.

Soni, A. (2015). Urus Ijin Usaha di Singapura, Cukup 1 Hari, diakses pada tanggal 15 Mei 2016, http://birokrasi.kompasiana.com/2013/1 0/19/urus-izin-usaha-di-singapuracukup-1-hari-600423.html. 